\title{
ОСОБЛИВОСТІ МОРФОМЕТРИЧНИХ ЗМІН АРТЕРІАЛЬНИХ СУДИН НИРОК ПРИ ПОРУШЕННІ ПРИТОКУ КРОВІ ДО ОДНІЄ З НИХ
}

\author{
(СО. Я. Галицька-Хархаліс
}

\author{
ДВНЗ "Тернопільський державний медичний університет імені I. Я. Горбачевського МОЗ України"
}

PЕЗЮМЕ. В експерименті на щурах вивчено динаміку морфометричних показників судин нирок та гістологічно перебудови нирково тканини після стенозу та наступно реканалізаці ліво нирково артері . Досліджено динаміку змін функціонального стану артерій нирки, як на боці патологі, так і з протилежного боку. Встановлено поглиблення морфофункціональних змін у ранні терміни після реперфузі і поступове часткове відновлення структурно організаці судин у більш віддалені терміни.

КЛЮЧОВІ СЛОВА: стеноз, нирки, спазм, артері, реперфузія.

Вступ. Сучасний стан проблеми розладів кровопостачання внутрішніх органів обумовлений X значною частотою серед інших патологічних процесів [1]. Поширеність патологі, в основі яко лежать порушення кровотоку, вимагають розробки і адекватного застосування засобів, що впливають на патогенетичний механізм цих порушень і викликають регресивні зміни в ушкоджених органах та тканинах [2]. Структурно-функціональна перебудова судинного русла внутрішніх органів $\epsilon$ важливою морфогенетичною ланкою у розвитку більшості захворювань і визначає ефективність адаптаційних і дезадаптаційних процесів організму.

Серед основних тенденцій досліджень у зазначеній сфері патологі на сьогоднішній день загальновизнаним залишається той факт, що порушення кровотоку, зокрема в нирці, призводять до значних змін мікроциркуляці, тканинного дихання, прогресування склеротичних процесів у паренхімі [3]. Однак, термін виникнення компенсаторнопристосувальних змін та динаміка $x$ перебігу під час порушення кровопостачання нирок на сьогодні ще остаточно не з'ясовані. Разом з тим, на даний час відсутні дані про відмінності в динаміці змін морфометричних характеристик нирок при односторонньому порушенні гемоциркуляці, а саме при стенотичному ураженні нирково судини.

Метою нашого дослідження було встановити особливості морфометричних змін артеріальних судин нирок при порушенні притоку крові до одніє з них.

Матеріали і методи дослідження. Дослідження проводили на 54 білих безпородних різностатевих щурах масою 180-200 г. Моделювання стенозу ліво нирково артері здійснювали 48 щурам, 6 тварин ввійшли в інтактну контрольну групу. Накладену на судину лігатуру утримували 1, 3, 7, 15 і 30 діб у 30-ти щурів, після чого х виводили з експерименту. Решті тварин модельований семиденний стеноз ліво нирково артері змінювали на реканалізацію ціє судини на 1, 3 та 7 доби шляхом обережного виведення через зашиту операційну рану опори. Після виведення тварин із експерименту шляхом введення великих доз концентрованого тіопенталу натрію проводили забір морфологічного матеріалу. При виконанні досліджень дотримувались міжнародних принципів «Європейсько конвенці про захист хребетних тварин, які використовуються для експериментів та інших наукових цілей» (Страсбург, 1985), Хельсинсько деклараці Генерально асамбле Всесвітньо медично асоціаці (2000).

Результати й обговорення. У процесі дослідження було встановлено, що внутрішньоорганні судини і право, і ліво нирок зазнали певних змін, в основі яких лежить вазоконстрикція, на що вказував ріст індексу Вогенворта (IB). Однак даний процес зліва і справа відрізнявся за інтенсивністю. Він був значно вираженіший на протилежному від патологічного процесу боці, оскільки права та ліва нирки перебували у різних гемодинамічних умовах.

Зменшення притоку крові до нирки зліва призвело до звуження просвіту дугових (ДА) і міжчасточкових артерій (МЧТА) з одночасним зниженням тонусу міжчасткових артерій (МЧА) на початкових етапах. Ці зміни мали реактивнопристосувальний характер і приводили судини у відповідність до рівня х Функціонування $[4,5]$. Описані судинні реакці спершу сприяли підтримці гомеостазу ренального кровообігу і забезпечували необхідний рівень клубочково фільтраці та нормальне функціонування нирок. Однак в подальшому вони швидше за все ставали причиною гіпоксі і призводити до проліфераці сполучно тканини.

Судинні реакці справа на всіх рівнях галуження спочатку були спрямовані на зниження пропускно здатності з метою запобігання перевантаженню гемомікроциркуляторного русла, яке могло бути наслідком підвищення тиску, як реакці організму на зниження фільтраці зліва з виділенням реніну [6]. Тому на всіх рівнях галуження нирково артері IB наростав, хоча в подальшому процес стабілізувався, а відновлення нирково перфузі могло складати підґрунтя для гіперпластичних процесів. 


\section{Оеляди літератури, оригінальні дослідження, поеляд на проблему}

Разом з тим, раптове відновлення кровообігу через звужену артерію супроводжувалося розвитком так званого «реперфузійного синдрому», який виникав внаслідок одночасного гемодинамічного і кисневого “удару", що призвело у реперфузійному періоді до поглиблення розладів органно гемодинаміки з порушенням обміну в органах і тканинах, які можуть в подальшому відігравати важливу роль у розвитку морфофункціонально недостатності [7]. Відновлення кровотоку через попередньо стенозовану ниркову артерію супроводжувалося вираженою тонічною реакцією судинно стінки артерій усіх рівнів галуження, як право, так і ліво ниркових судин (рис. 1, 2). Слід відмітити, що інтен-

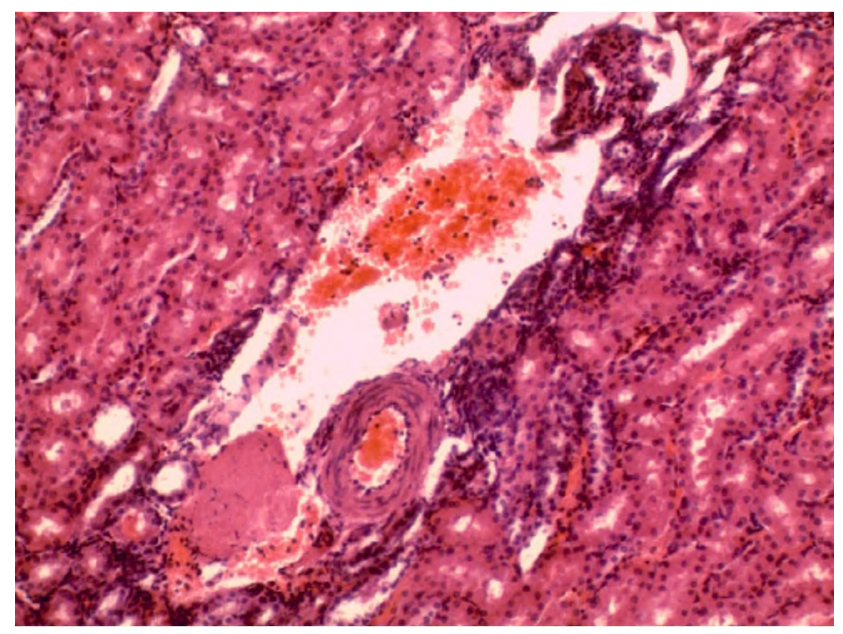

Рис. 2. Тканина ліво нирки у щура на 1 добу після реканалізаці 3 канальцевим та периваскулярним набряком. Забарвлення за Вейгертом. Зб. × 320.

Зокрема такі, дещо відмінні між собою, патогенетичні механізми розвитку реперфузійного синдрому в обох нирках, швидше за все, зумовлюють відповідну регресію досліджуваних змін. Тому зліва показники функціонального стану артеріальних стінок швидше повертаються до контрольного рівня, ніж у контрлатеральній нирці, проте повного відновлення структури судин не відбувається.

Висновки. 1. У процесі розвитку стенозування ліво нирково артері в судинних руслах право та ліво нирок виникають характерні та водночас дещо відмінні між собою зміни. На ранніх стадіях вони проявляються вазоконстрикцією на всіх рівнях галуження справа та вазодилатацією МЧА зліва з одночасним зниженням пропускно здатності ДА М МЧТА.

2. Більш інтенсивна вазоконстрикція справа спрямована на захист гемокапілярного русла від підвищення артеріального тиску, яке закономірно виникає внаслідок зниження клубочково фільтраці зліва. Поєднання вазодилатаці МЧА з одночасним зниженням пропускно здатності ДА і МЧТА сивність реперфузійних змін зліва була дещо вищою, ніж справа, на першу добу експериментального дослідження. Найімовірніше, що зліва така динаміка виникала в результаті захисно реакці на різке гемодинамічне навантаження через посилення кровотоку в судинному басейні ліво нирки. Разом з тим, справа таке посилення опірності судинного русла закономірно з'являлося як відповідь на посилений викид у загальний кровотік вазоактивних речовин, що, в свою чергу, продукувались юкстамедулярним апаратом ішемізовано нирки з протилежного боку і інтенсивність цього процесу прослідковувалася вже на третю добу після реканалізаці ліво нирково артері.

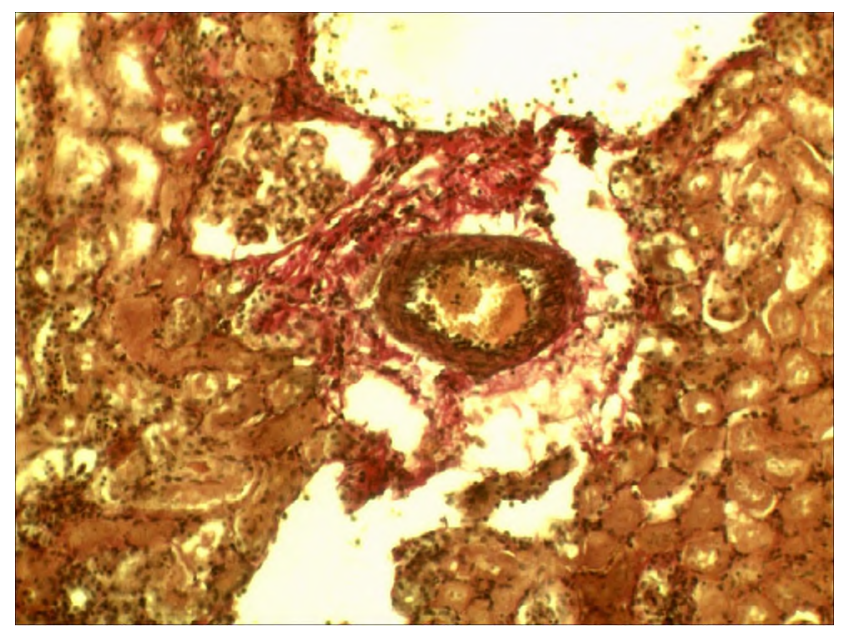

Рис. 1. Тканина право нирки у щура на 1 добу після реканалізаці : мозкова частина - набряк епітелію канальців. Забарвлення гематоксиліном і еозином. Зб. × 160.

зліва може бути спрямоване на підтримання відповідного рівня внутрішньосудинного тиску та достатнього тканинного живлення за умов центрально гіпоперфузі.

3. Відновлення прохідності попередньо стенозовано ліво нирково артері на ранніх стадіях реперфузі супроводжується поглибленням морфофункціональних змін, що виникають в судинах обох нирок, та розвитком реперфузійного синдрому з розвитком дегенеративних та деструктивних процесів в нирках. Підвищення тонусу артерій зліва виникає в результаті захисно реакці на різке гемодинамічне перевантаження, тоді як справа така ж динаміка зумовлена впливом вазоактивних речовин.

4. По мірі стабілізаці органно гемодинаміки при адаптаці кровоносного русла до функціонування в умовах реперфузі в елементах судинних стінок відбуваються зворотні процеси, однак повного відновлення структур не відбувається.

Перспективи подальших досліджень. Отримані результати можуть бути використані для обґрунтування нових методів корекці стенозування нирково артері, а також корекці судинних 
Оеляди літератури, ориаінальні дослідження, поеляд на проблему

змін внутрішньоорганно нирково гемодинаміки різного ґенезу та стати підґрунтям для подальшо розробки нових методів лікування стенозу нирково артері.

\section{ЛІТЕРАТУРА}

1. Патофизиологическая природа и патогенетическая коррекция реперфузионного синдрома с реперфузионным повреждением / Л. Г. Кононенко, А. В. Прохоров, М. А. Тучинская [и др.] // Вісник Сумського державного університету. Серія Медицина. - 2006. - № 2 (86). C. $166-171$.

2. Ромашкіна О. А. Особливості структурно перебудови нирок при експериментальному атеросклерозі та його корекці / О. А. Ромашкіна, Р.П.Піскун // Вісник проблем біологі та медицини. - 2011. - Вип. 2, Т. 2. C. $239-241$.

3. Патоморфологічні зміни нирок під час ішемі / О. В. Люлько, Я. М. Підгірний [i iн.] // Медичні перспективи. - 2006. - Т. 11, № 3. - С. 16-25.

4. Cooper C. J. Is renal artery stenting the correct treatment of renal artery stenosis? The case for renal artery stenting for treatment of renal artery stenosis / C. J. Cooper, T. P. Murphy // Circulation. - 2007. - Vol. 115(2). P. 263-269.

5. Dworkin L. D. Is renal artery stenting the correct treatment of renal artery stenosis? Case against angioplasty and stenting of atherosclerotic renal artery stenosis / L. D. Dworkin, K. A. Jamerson // Circulation. - 2007. Vol. 115(2). - P. 271-276.

6. Knight $S$. Renal functional responses to ischaemia reperfusion injury in normotensive and hypertensive rats following non-selective and selective cyclo-oxygenase inhibition with nitric oxide donation / S. Knight, E. J. Johns // Clin. Exp. Pharmacol. Physiol. - 2008. - Vol. 35, № 1. - P. 11-16.

7. Revascularization versus Medical Therapy for RenalArtery Stenosis / Dr. Wheatley, Ms. Ives, Dr. Kalra and Dr. Moss //N. Engl. J. Med. -2009. - Vol. 361. - P. 1953-1962.

\title{
MORPHOMETRIC FEATURES CHANGES OF RENAL VASCULAR FOR BREACH BLOOD FLOW TO ONE OF THEM
}

๑O. Ya. Halytska-Kharkalis

\author{
SHEI «Ternopil State Medical University by I.Ya. Horbachevsky of MPH of Ukraine»
}

SUMMARY. In an experiment on rats studied the dynamics of morphometric parameters of renal vascular and renal histological tissue reconstruction after stenosis and subsequent recanalization of the left renal artery. The dynamics of changes in the functional state of the kidney arteries on both the pathology and on the opposite side was investigated. Established deepening morphofunctional changes early after reperfusion and gradual partial recovery of the structural organization of the vessels in a more remote period.

KEY WORDS: stenosis, kidney, spasm, artery, reperfusion. 